\section{Librarians March for Science}

Science librarians were well-represented in the March for Science on Earth Day, April 22 , in cities from coast-to-coast, from the heartlands to the deep south and the far west. The March for Science drew tens of thousands of scientists, science communicators, and science enthusiasts worldwide, with a mission statement that was strictly nonpartisan.

"It was both exhilarating and exhausting in Washington, D.C., where we spent five hours standing in the rain at the foot of the Washington Monument," said Alison S. Ricker, head of the Science Library at Oberlin College. "Inspiring messages from speakers and good music kept us energized for the eventual march along Constitution Avenue toward the U.S. Capitol. By the time we passed the EPA building, marchers and spectators

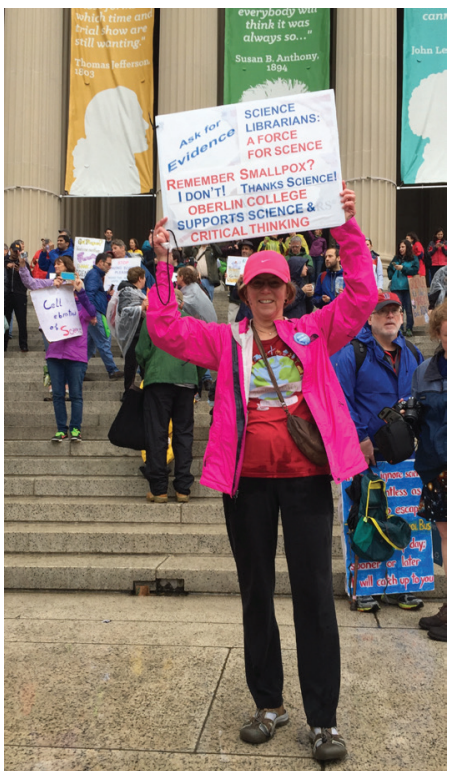

Alison Ricker of Oberlin College at the Washington, D.C., March for Science. were full of enthusiasm, shouting 'fund the EPA!' and 'alternative facts have got to go!"

In addition to the March in Washington, D.C., there were 610 registered satellite marches to "acknowledge and voice the critical role that science plays in each of our lives." The March for Science website links to a website or social media page for every march, where summaries of speeches, photos, videos, and estimated attendance numbers attest to the outpouring of support for science and, just as fervently, evidence-based policy, and legislation. Read online comments from librarian participants across the country at http://bit.ly/2q61VYr and learn more about the march at https://marchforscience.com.

\section{ACRL Legislative Agenda}

Each year, the ACRL Government Relations Committee, in consultation with the ACRL Board of Directors and staff, formulates an ACRL Legislative Agenda. Drafted with input from key ACRL committees, ACRL leaders, and the ALA Washington Office, the ACRL Legislative Agenda is prioritized and focuses on issues at the national level affecting the welfare of academic and research libraries.

The 2017 ACRL Legislative Agenda focuses on four issues that the U.S. Congress has recently taken, or will most likely take, action on in the year ahead: federal funding for libraries, network neutrality, access to federally funded research, and privacy and government surveillance. The agenda also includes a watch list of policy issues of great concern to academic librarians. Legislation on these issues is not likely to arise and, moreover, ACRL does not believe that any legislation about these issues is necessary.

Issues on the watch list are: access to government data, proposed budget cuts, and the activities of the Congressional House Education and the Workforce Committee. ACRL will continue tracking these issues and advocate for the best interests of academic and research libraries, if necessary. The complete agenda is available at www.ala.org/acrl/issues/washingtonwatch/legagenda.

\section{NCLA launches CUS Webinar Wednesday}

The North Carolina Library Association's College and University Section (CUS) has 


\section{New ACRL books focus on information literacy instruction, mobile technology}

ACRL announces the publication of Reading, Research, and Writing:Teaching Information Literacy with Process-Based Research Assignments, by Mary Snyder Broussard, and Mobile Technology and Academic Libraries: Innovative Services for Research and Learning, edited by Robin Canuel and Chad Crichton.

Through theory and examples, and with ACRL's Framework for Information Literacy for Higher Education integrated throughout, Reading, Research, and Writing shows just how difficult research assignments can be for novice learners, and offers concrete plans and approaches for building assignments that enhance student

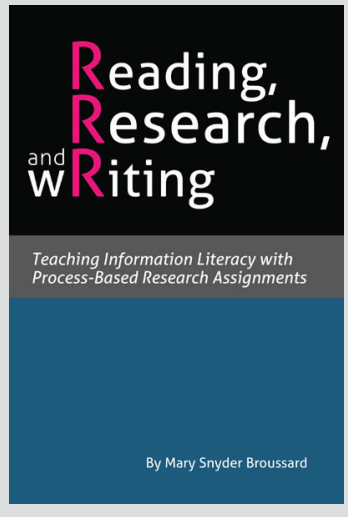
learning.

In six chapters-including a final chapter on turning theory into practice-this book is an in-depth, interdisciplinary look at the literature in rhetoric and composition studies, reading comprehension, cognitive psychology, education theory, and library and information science that captures what academic librarians and their teaching faculty collaborators should know about reading and writing to improve undergraduate writing-from-sources assignments.

Mobile Technology and Academic Libraries is a detailed and thorough examination of technology that's emerging now, and how to incorporate it into your library to help the students and researchers of both today and tomorrow. Mobile technology has become a ubiquitous presence in the lives of students and faculty.
The maturing of this technology has led to our becoming more and more comfortable in a world where digital information flows seamlessly from screen to screen as we move about our daily lives. This evolution presents both risks and opportunities for academic librarians, operating in a field that is both uniquely tied to a static sense of "place" in the public imagination and at the same time passionately devoted to the freedom, spread, and accessibility

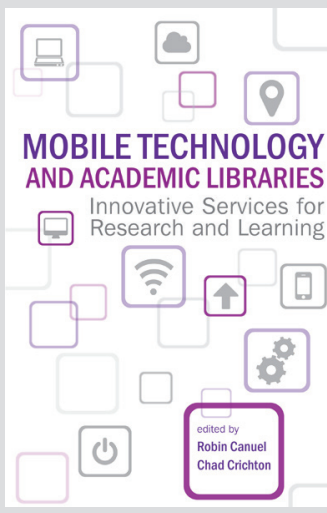
of information for the public at large.

In 17 chapters ranging from A MobileFirst Library Site Redesign to Virtual Reality Library Environments, Mobile Technology and Academic Libraries explores how librarians around the world are working to adapt their spaces, collections, teaching, and services to the new possibilities presented by mobile technology.

Leveraging the potential of smartphones, tablets, and even wearable technologies allows academic librarians to further expand their reach to students and faculty beyond the library's walls

Reading, Research, and Writing:Teaching Information Literacy with Process-Based Research Assignments and Mobile Technology and Academic Libraries: Innovative Services for Research and Learning, are available for purchase in print and as an ebook through the ALA Online Store; in print through Amazon. com; and by telephone order at (866) 746 7252 in the United States or (770) 442-8633 for international customers. 
launched a monthly webinar series titled CUS Webinar Wednesday. These multidiscipline webinars began as a state-wide professional development opportunity for North Carolina CUS members, but have since grown to include national participation. As an extension of the webinar series, CUS's first one-day virtual conference was successfully held in February 2017, with participation from a diverse group of libraries across the nation as well as a few attendees from Canada and Mexico.

These informative 40-minute webinars provide the opportunity for librarians to present concise online sessions on their research, knowledge, and experience to their peers. Thus far, presentations on intentional course design, e-textbooks, and gamification, to name a few, have been successfully hosted and archived. Additional information, including the webinar schedule and proposal link, can be found at www.nclaonline.org /college-university.

\section{OCLC Research publishes guide for collaboration between archivists and IT professionals}

OCLC recently released "Demystifying IT: A Framework for Shared Understanding between Archivists and IT Professionals," a report in the Demystifying Born Digital series designed to help archivists achieve a better understanding of how information technology professionals work so that they can be effective collaborators. The report by Seth Shaw, Clayton State University; Richard C. Adler, University of Michigan Library; and Jackie Dooley, OCLC Research, describes types of IT providers and the services they typically offer, offers insights on the software development process, provides guidance toward building partnerships, and

\section{Mountain Plains Library Association supports ACRL Diversity Alliance}

The Executive Board of the Mountain Plains Library Association (MPLA) has voted to formally support the goals of the ACRL Diversity Alliance. MPLA will encourage academic institutions in its 12 member states (Arizona, Colorado, Kansas, Montana, Nebraska, Nevada, New Mexico, North Dakota, Oklahoma, South Dakota, Utah, and Wyoming) to participate in establishing residency programs for professionally underrepresented racial and ethnic groups in the library profession.

"Academic librarians play an important role in our MPLA membership, representing over $35 \%$ of our membership," said MPLA President Mickey Coalwell. "This action by the MPLA Executive Board directly supports two of the Guiding Principles from MPLA's new Strategic Plan-pursuing outreach opportunities in the 12-state MPLA region and realizing the potential of our multi-state collaboration through leadership development, professional growth opportunities for members, and engagement with the larger library community."

MPLA will pay one-half of the institution's $\$ 500$ first-year participation fee, and will pay the cost of MPLA membership for the duration of the chosen candidate's residency at the institution.

The Arizona State University Library recently became the first MPLA member institution to sign on for the MPLA/ ACRL Diversity Alliance partnership.

More information about the ACRL Diversity Alliance, including a list of participating institutions, is available on the ACRL website at www.ala.org/acrl/issues /diversityalliance. Learn more about MPLA at www.mpla.us. 
emphasizes the centrality of resource constraints. Many of the issues described are relevant to librarians and archivists who work with IT colleagues on issues other than born-digital management. The report is available for download from the OCLC Research website at www.oclc.org/research/publications /2017/oclcresearch-demystifying-it -shared-understanding.html.

\section{Performing Arts Readiness website launches}

The Performing Arts Readiness project, which supports a variety of programs to increase the knowledge and ability of performing arts organizations to create and execute emergency recovery plans, launched a new website this May. LYRASIS is administering this threeyear project that is funded through a grant from the Andrew W. Mellon Foundation and was created to address the vulnerability of performing arts organizations to emergencies and disasters that can damage business operations and artistic legacy.

The Performing Arts Readiness project will soon offer free webinars and onsite training, conference presentations, grants, and tools to help build the field's capacity for disaster preparedness. The website is available at http://performingartsreadiness. org.

\section{ACRL Instruction Section releases Tips and Trends: Accessibility and Universal Design}

The ACRL Instruction Section Instructional Technologies Committee, has published their latest Tips and Trends article, "Accessibility and Universal Design," written by Bonnie L. Fong, Elizabeth M. Johns, and Becka Rich. Tips and Trends introduces and discusses new, emerging or even familiar technologies that can be used in library instruction. "Accessibility and Universal Design" is freely available at bit.ly /tipsandtrendsw17.

\section{Tech Bits ...}

\section{Brought to you by the ACRL ULS Technology in University Libraries Committee}

Tired of using cumbersome PowerPoint decks to create Jeopardy-like games? Or perhaps you do not even bother creating games because they are too time consuming. FlipQuiz does the hard work for you, making Jeopardy-like games easy to create and use for free. As a web-based tool, it can be accessed anywhere with an Internet connection. The free version works on mobile devices, but the pro version optimizes FlipQuiz so it will work better on personal handheld devices. FlipQuiz can be used as an engagement strategy in the classroom, to help facilitate review sessions, and as flashcards for students to study. Librarians might find this particularly useful in orientation sessions to help students learn about the library.

—Elizabeth M. Johns Johns Hopkins University

... FlipQuiz

https://flipquiz.me/

\section{NCSU Libraries announces Library Fellows class}

The North Carolina State University (NCSU) Libraries has announce its incoming class of Library Fellows for 2017-19. The Fellows Program develops future leaders for academic libraries, with a focus on science, engineering, digital librarianship, diversity, and library management. Fellows are appointed for a two-year term as members of the library faculty, combining an assignment on an initiative of strategic importance with an appointment in a home department. For more than 15 years, the program has attracted talented new graduates from universities throughout North America. The 2017-19 NCSU Libraries Fellows are Nicola Andrews, Shelby Hallman, Erica Hayes, and Colin Nickels. $\boldsymbol{n}$ 